\title{
Make or buy: train in-company or recruit from the labour market?
}

\author{
Lutz Bellmann ${ }^{1,2^{*}}$, Philipp Grunau ${ }^{2}$, Klaus Troltsch ${ }^{3}$ and Günter Walden ${ }^{3}$
}

\author{
* Correspondence: \\ lutz.bellmann@iab.de \\ ${ }^{1}$ Friedrich-Alexander University \\ Erlangen-Nürnberg, Nürnberg, \\ Germany \\ ${ }^{2}$ Department "Establishments and \\ Employment", Institute for \\ Employment Research (IAB), \\ Nürnberg, Germany \\ Full list of author information is \\ available at the end of the article
}

\begin{abstract}
Background: Using a sample about company hiring behaviour from the BIBB Establishment Panel on Training and Competence Development 2011, this paper analyses the hiring decisions of German establishments. Companies essentially have two choices to meet their labour demands: to provide their own apprenticeship training or to recruit unskilled or already-qualified staff through the external labour market.

Methods: Therefore, we employ a multinomial quasi-maximum likelihood fractional regression model that simultaneously investigates the determinants of five hiring alternatives (new trainees, external unskilled staff, external skilled staff with initial vocational education, technicians and master craftsmen, and external staff with higher education).

Results: Our analysis reveals that a firm's characteristics play a crucial role in explaining its recruitment behaviour. In this respect, the mobility and development of its workforce as well as the reproduction of the existing qualification structure prove especially important.

Conclusions: The empirical results further show some evidence that apprenticeship training and the recruitment of workers with IVET qualifications from the external labour market depict alternative strategies.

Article classification: $1-21$; J-23; J-63

Keywords: Vocational training; External recruitment; Multivariate fractional regression
\end{abstract}

\section{Introduction}

To meet their demands for qualified workers, companies essentially choose between providing their own initial vocational education and training (IVET) or recruiting differently qualified staff from the external labour market. In Germany, the overriding importance ascribed to in-company apprenticeship training has traditionally affected this decision. Over their lifetimes, more than 50 per cent of a given school leavers cohort will have received basic occupational training through the dual IVET system (Gericke, 2014), which includes firms and part-time vocational schools as learning venues. However, the choice of whether and which individuals should participate in an initial vocational training programme rests exclusively with the companies. The following paper therefore focuses on the question of which different key company-related factors the recruitment of new apprentices and (unskilled and skilled) workers from the external labour market fundamentally depends on.

Starting with a company's decision to train or not to train, we regard the recruitment of unskilled workers, vocationally qualified workers, technicians and master craftsmen and academically educated workers from the external labour market. There is immediate

(c) 2014 Bellmann et al.; licensee Springer. This is an Open Access article distributed under the terms of the Creative Commons Attribution License (http://creativecommons.org/licenses/by/4.0), which permits unrestricted use, distribution, and reproduction in any medium, provided the original work is properly credited. 
evidence about the existing relationship between apprenticeship and recruiting skilled workers from the external labour market (Bellmann and Janik, 2007; Troltsch and Walden, 2010). We further suppose that recruiting other groups of staff like unskilled workers or university graduates depends both on the hiring of other groups and on part of the recruiting policy of the company. Therefore, we analyse whether there are common or different patterns of factors that determine, on the one hand, the recruitment of apprentices and, on the other hand, the recruitment of different groups of workers from the external labour market.

The relative attractiveness of all of these basic recruitment options is of vital importance for the significance of the German vocational education and training (VET) system. However, no overarching research approaches explain why companies opt for a particular variant of skilled-worker recruitment or a combination of several strategies. The following paper therefore takes Wolter and Ryan's research question as a starting point: among other aspects, they studied the 'substitutability in production between apprentice and other labour (skilled and unskilled)' (Wolter and Ryan, 2011, p. 538).

The paper is structured as follows: the background section will describe theoretical approaches that explain the make-or-buy decision; the few relevant empirical studies on this topic are also introduced in this section as well as hypotheses about the interaction of different recruitment strategies. The results and discussion section presents the empirical findings on the make-or-buy decision. In the subsequent section we discuss some conclusions. The final methods section presents the dataset, the selected variables and the econometric methodology.

\section{Background}

\section{Theoretical foundations}

In our view, two approaches are relevant as theoretical foundations to study companies' make-or-buy decisions. On the one hand, some approaches explain firms' willingness to train employees in the tradition of human capital theory. On the other hand, the task approach in the context of labour economics provides insights to analyse this decision.

Economics of education approaches in the tradition of human capital theory (Becker, 1964) explain companies' involvement in training in terms of investment in companyspecific human capital and that investment's positive returns. Specific human capital encompasses qualifications that can only be put to use in the company that provides the training. General human capital, in contrast, is transferable to other companies. As apprentice training in Germany, and in other countries such as Switzerland and Austria, is legally regulated to ensure that qualifications are transferrable beyond a particular company's confines, it can be assumed that the majority of the qualifications imparted during apprentice training represents investment in Becker's sense of general human capital. Companies would consequently view this type of investment as excessively risky because trainees would be more likely to leave or be lured away to other firms; therefore, these companies might be expected to recruit already-trained skilled workers from the external labour market. In-company training of skilled workers would then cease to be a worthwhile recruitment strategy.

Economics of education refinements no longer rely on the assumption of perfect labour market competition and come to an alternate conclusion that justifications can be derived for corporate investment in general human capital. Katz and Ziderman 
(1990) examine information-based costs as an obstacle for labour mobility and an incentive for establishments to invest in general human capital. Stevens (1994) argues that the costs of recruiting already-qualified skilled workers can be a motive to invest in company IVET: 'If firms face high costs or difficulties in recruiting skilled labour, they can offset costs incurred in the training of apprentices against these ... (and they) do regard it as an investment' (p. 568-569). Acemoglu and Pischke (1998, 1999a, 1999b) see the potential for firms to achieve longer-term investment returns. Aside from the reasons Acemoglu and Pischke cite for investing in general human capital, attention is drawn to the possibility that trainees themselves could finance such an investment. In the 'production model' of training (Lindley, 1975), trainees finance their training through parallel employment on the production side. In the 'investment model' of training (Merrilees, 1983), training costs exceed training returns during the training period, and companies depend on longer-term returns that only accrue after the training phase is completed ${ }^{\mathrm{a}}$. In the different approaches of human capital theory, alternative recruitment options to training apprentices consist of recruiting both skilled and non-skilled workers from the external labour market but not higher qualified staff, such as university graduates.

A key approach in labour economics is the task approach that Autor et al. (2003) developed to explain the link between job requirements, the demand for workers with different qualifications, and changes in technology. This theoretical approach differentiates between three qualification groups (high, middle, low) and two task types (routine and non-routine). The task approach sees higher-qualified skilled staff being relieved of routine tasks through technological changes, particularly the computerisation of certain tasks. Consequently, the demand for university graduates rises. However, skilled workers in the intermediate qualification segment often perform routine tasks. Thus, skilled workers could be replaced by computerisation, and the demand for skilled workers on the intermediate level would fall. The task approach also assumes a high share of non-routine tasks for unskilled workers, meaning that computerisation here (e.g., cleaning and truck driving) is not (yet) possible. Consequently, unskilled workers cannot be replaced in the same way as skilled workers. These labour market effects, summarised under the headline of polarisation, would reduce the demand for vocationally qualified skilled workers from the intermediate qualification segment but increase the demand for university graduates and unskilled workers. According to this approach, there would consequently be less incentive to train skilled workers.

\section{Current state of research}

The main body of make-or-buy decision research includes empirical studies on factors that influence the level of company-based apprenticeship placement offerings in Germany and firms' willingness to provide in-company IVET. This research suggests that objective framework conditions that address factors such as the company's business expectations or situation (Dietrich and Gerner, 2007) or employment trends (Troltsch and Walden, 2010) are highly significant in determining whether to provide in-company IVET. Studies of in-company IVET in Switzerland also attest to a strong correlation between the number of company-based apprenticeship places and companies' employment structures (Muehlemann et al., 2007). In Germany (Walden, 2007a) and Switzerland (Muehlemann et al., 2007), a significant negative correlation has been 
observed between the level of company IVET costs and the number of apprenticeship places.

Analyses of whether companies choose to engage in IVET - irrespective of the number of apprentices involved - result in clear correlations, both in Germany and Switzerland, between underlying company data, such as employment demand in relevant qualification areas, the existence of employee representative bodies, in-company continuing vocational education and training CVET, and, not least, company size or industrial sector (Muehlemann et al., 2007; Schweri and Müller 2007; Walden, 2007a). A factor of particular importance is whether the company employs already-trained and suitably qualified skilled workers from the intermediate qualification segment and whether this choice results in a certain preference for IVET. Among the more influential framework conditions are institutional structures such as workforce representative bodies. Recent studies on this topic have found that companies with works councils report higher net investments in IVET, and these companies' longer-term apprentice retention rates are higher (Kriechel et al., 2012), with both indicators pushing for companies to increase training participation. Bellmann et al. (2010) analysed the correlation between in-company IVET and CVET and found that both main company qualification segments are predominantly complementary, with no apparent evidence of substitutive relations. Regarding company size, existing studies demonstrate that far larger proportions of large firms than smaller firms act as 'training companies', i.e., IVET providers. A similar finding applies to economic sectors, i.e., training participation in the service sector is traditionally lower than in manufacturing (Walden, 2007b).

Regarding the importance of apprenticeship training empirical studies show that firms with a strong internal labour market tend to have higher shares of apprentices than companies where the recruitment of skilled workers primarily takes place via the external labour market (e.g. Beicht et al. 2004). Companies with a well-developed internal labour market on average also invest more into continuous vocational training. These principal orientations of human resource policies in companies could affect the decision for different recruiting options.

To the best of our knowledge, the only studies that have thus far directly compared the alternatives of in-house IVET and external labour market recruitment are those by Bellmann and Janik (2007) in Germany and Blatter et al. (2012) in Switzerland. Starting with the degree of uncertainty about how many apprentices a firm can hire at the completion of the apprenticeship period, Bellman and Janik analyse possible correlations, differentiating between the production and service sectors. Although they find no correlations between the degree of uncertainty and in-house IVET in the production sector, they discover a negative correlation in the service sector. Moreover, companies facing a high degree of uncertainty more frequently opt for external labour market recruitment. Blatter et al. (2012) consider how costs affect the choice between recruitment and training. According to their results, companies are particularly likely to invest in additional apprenticeship places when the average costs of recruiting workers from the external labour market increase. If, however, the average net cost of IVET increases, the number of training places offered by these firms declines.

One shortcoming of the aforementioned studies is that no distinction is made between the recruitment of skilled workers with intermediate vocational qualifications and the recruitment of other qualified workers ${ }^{c}$. In analysing companies' make-or-buy 
decisions when recruiting workers from the external labour market, this paper will therefore differentiate between the unskilled workforce, workers with an intermediate level of vocational qualifications, tertiary vocational graduates (i.e., technicians and master craftsmen) and higher education graduates. At this point, no general study of German companies' recruitment practices has been conducted.

\section{Hypotheses}

The mentioned explanatory approaches and empirical findings about various alternative labour recruitment strategies might be assumed to substantially depend on the company's internal framework conditions. We take as a starting point factors that affect the cost-benefit ratio for apprenticeship training and regard other potentially relevant factors for the decision to train or recruit different groups of workers from the external labour market. We distinguish the following aspects: employment-related factors (e.g., companies' employment structures), structure-related features (e.g., company size, sector and region), institution-related factors (e.g., the company's affiliation to collective agreements), factors that are related to worker mobility (e.g., the company's churning rate and other indicators), and cost-related features (e.g., wages). We also consider skill-related factors, such as further in-company training, and factors that are related to the companies' technological and market strategies. These factors will influence the companies' recruitment decisions in different ways.

However, our central analytical interest specifically refers to those factors that are relevant in assessing in-company IVET's significance. Therefore, we will only present a few selected hypotheses about company characteristics' impact on the make-or-buy decision. In our first hypothesis, we propose a positive relationship between in-company vocational training and the company's evaluation of apprenticeship training's costbenefit ratio. But it is not sufficient to just take firms' perception of costs as a covariate, as costs have to be seen in comparison to the benefits. Therefore, we also include the evaluation of benefits in our analysis. Costs and benefits both are dependent on the basic conditions for training in the company.

In our second hypothesis, we assume a negative relationship between apprentice recruitment and labour mobility in the respective companies. A central motivation for companies to train their personnel is to meet the future demand for skilled labour. In case of a high turnover of employees the benefits of training as perceived by the firm should be lower, as there would be a higher risk that - after completion of training apprentices might leave the firm and the investment in human capital would be lost.

In our third hypothesis, we examine whether there is a positive relationship between apprentices and the internal institutional environment, such as works councils and the company's affiliation to collective agreements. In many companies in Germany, legislation called the Works Constitution Act provides for works councils or staff councils to be involved in the decision to train young people. In certain branches of industry, arrangements for young people's vocational education have been specified in collective agreements. We propose that the firm's training probability is higher in this institutional context.

In our final hypothesis, we assume a negative relationship between companies' apprenticeship training and certain types of cost-minimizing business strategies. Michael Porter (2004) draws a fundamental distinction between a cost leadership strategy and 
other strategies that mainly emphasize a higher quality of products and services (differentiation and focus strategies). Companies that take the cost leadership strategy should tend more to recruit skilled labour from the external labour market.

In addition, we also propose a strong relationship between the company's employment structures and its probability to choose a certain form of recruitment strategy (i.e., path dependency). We also propose that there are specific relationships between apprentice recruitment and other recruitment options that depend on different influential factors. According to different demands for skilled labour companies should practice combinations of recruitment options (e.g. recruiting apprentices and unskilled labour or university graduates and apprentices at the same time). Hence, our approach should allow for the fact that different combinations are not affected by the same potentially relevant factors.

Due to the present study's methodological approach, we can only formulate preliminary evidence regarding the question of whether the different recruitment options are rather compatible or opposing.

\section{Methods}

\section{Data and Variables}

To pursue the lines of enquiry set out in the previous section of this paper, we need information about company hiring behaviour. For this purpose, we refer to the Establishment Panel on Training and Competence Development of the Federal Institute for Vocational Education and Training (BIBB) in Bonn, which provides detailed data on the volume of filled and unfilled training slots and unskilled and skilled-worker positions $^{\mathrm{d}}$. Alternative company surveys in Germany, such as the IAB Establishment Panel survey, are not suitable for this study because they do not differentiate required qualification levels for their filled or unmet recruitment demand for new apprentices and already-qualified workers.

With support of the Federal Employment Agency since 2011, TNS Infratest has used CAPI interviews to conduct the annual BIBB Establishment Panel on Training and Competence Development, a representative survey of German companies about training and competence development. In the course of this analysis, we use the first wave of data from 2011, which contains information on 2,004 establishments. The sample is based on the total population of German establishments with at least one employee who is subject to social security contributions. After employing imputations, we have information on model variables for 1,888 of these establishments $(94.2 \%)^{\mathrm{e}}$. Of this number, 342 establishments reported no demand for new apprentices or unskilled/skilled workers from the labour market during the observation period, bearing in mind that demand may refer to either satisfied or unsatisfied demand. To avoid confounding effects between establishments with and without demand, the remaining 1,567 establishments, which do report some labour demand, are included in the study as described below. In the responses companies always refer to the last calendar year.

The aforementioned explanatory approaches to various alternative recruitment strategies might be assumed to substantially depend on the company's general framework conditions. Relevant factors to consider here include the economic situation and employment trends, companies' structural features (e.g., firm size), sector affiliation, churning rate, and existing employment structures. The status of further in-company 
training activities (Bellmann et al., 2010) and - because of the particular institutional conditions for dual-system IVET - the company's affiliation to collective agreements and the existence of a works council may also be significant. A firm's strategic market behaviour may be important as well, which is why we include variables indicating if an establishment frequently changes its products, focuses on new products and/or indicates price as the primary competitive factor.

\section{Description}

As can be seen in Table 1, approximately one in twelve establishments attempts to exclusively satisfy its reported labour demand by (the medium-term solution of) hiring new apprentices, compared with 60 per cent that exclusively opt for the external labour market recruitment. Most establishments (76 per cent) report at least some demand for already-qualified workers with IVET degrees (or with sufficient occupational experience), whereas only about one in four establishments opts to hire technicians and master craftsmen.

With an average demand share - among companies with a labour demand - of close to 42 per cent, the external recruitment of individuals with vocational qualifications has the greatest quantitative significance of the five demand-meeting channels that are considered in this study. At approximately 5 per cent, the recruitment of technicians and master craftsmen is the least-used demand-meeting strategy for qualified labour. The demand for new apprentices takes on one-fourth of total demand ${ }^{f}$.

As we suppose basic structural differences between firms' demand attributable to certain characteristics, we distinguished the content of Table 1 by sector affiliation. The respective statistics are displayed in Table S1 in Additional file 1. These unconditional descriptives reveal that while in manufacturing, commerce, and repair relative demand for new apprentices is highest, firms in the primary sector, public service, education and teaching tend to rely the most on already-qualified workers with IVET qualifications from the labour market ${ }^{\mathrm{g}}$.

Table 1 Structure of companies' recruitment behaviour in the sample (unweighted)

\begin{tabular}{|c|c|c|c|c|c|c|c|}
\hline \multirow[t]{3}{*}{$n=2,004$} & & \multicolumn{6}{|c|}{ Share of observed companies... } \\
\hline & & \multirow{2}{*}{$\begin{array}{l}\text { With no } \\
\text { demand } \\
\text { at all } \\
(\mathrm{n}=342)\end{array}$} & \multicolumn{5}{|c|}{$\begin{array}{l}\text { With demand for at least one apprentice/worker position } \\
\text { in one of the five channels to meet their labour demands } \\
(n=1,662)\end{array}$} \\
\hline & & & $\begin{array}{l}\text { With no } \\
\text { demand for } \\
\text { the given } \\
\text { group }\end{array}$ & $\begin{array}{l}\text { With a } \\
\text { demand of } \\
>0 \text { and }<100 \\
\text { per cent }\end{array}$ & $\begin{array}{l}\text { With exclusive } \\
\text { demand for the } \\
\text { given group }\end{array}$ & Mean & $\begin{array}{l}\text { Standard } \\
\text { deviation }\end{array}$ \\
\hline \multirow{5}{*}{$\begin{array}{l}\text { Demand } \\
\text { for... }\end{array}$} & New apprentices & \multirow[t]{5}{*}{17.1} & 40.1 & 51.9 & 7.9 & 24.9 & 31.5 \\
\hline & $\begin{array}{l}\text { External unskilled } \\
\text { workers }\end{array}$ & & 66.4 & 30.2 & 3.4 & 14.3 & 27.1 \\
\hline & $\begin{array}{l}\text { External skilled } \\
\text { workers with IVET } \\
\text { qualifications }\end{array}$ & & 23.7 & 61.7 & 14.6 & 41.9 & 35.2 \\
\hline & $\begin{array}{l}\text { Technicians and } \\
\text { master craftsmen }\end{array}$ & & 74.6 & 24.2 & 1.2 & 5.4 & 14.7 \\
\hline & $\begin{array}{l}\text { External skilled } \\
\text { workers with } \\
\text { university degree }\end{array}$ & & 60.0 & 36.9 & 3.1 & 13.5 & 24.6 \\
\hline
\end{tabular}


A statistical overview and description of the model's dependent and independent variables can be found in Tables S2 in Additional file 2 and Table S3 in Additional file 3.

\section{Econometric methodology}

In our dataset, every surveyed company reports an absolute figure for each of the five possible alternatives, the total of which represents that company's total demand for (unskilled and skilled) labour. Therefore, in our analysis, this total demand comprises the demands for (1) new training contracts, (2) unskilled workers and skilled workers, where the latter group is subdivided into (3) tasks that presuppose the completion of an IVET qualification or equivalent occupational experience, (4) tasks for technicians and master craftsmen and (5) tasks that require a higher education degree. To ensure the incorporation of the full labour demand, each of these single demands encompasses the realised (actual hires) and unrealised (unfulfilled vacancies) part of the labour category. To ensure comparability between different companies, it is possible to analyse this information by adjusting the figures according to a firm's size and use the total demand shares met through each channel, which amount to $100 \%$ of the total (or a value of 1). The studied demand-meeting options are thus viewed as interdependent and hence require simultaneous analysis.

The univariate case, in which only one proportion or $s$ share per establishment is analysed and for which papers by Papke and Wooldridge (1996, for cross-sectional and 2008 for panel data) represent crucial contributions to the literature, will not be discussed in detail. In the multivariate case that is the basis for the present paper $^{\mathrm{h}}$, the estimation can be performed either using conditional mean models or fully parametric models. Although the latter are usually based on maximum likelihood estimation, the conditional mean models use non-linear least squares or quasi-maximum likelihood estimators. In this paper, we adopt this method to model the (conditional) means $E[s \mid X]$ of the share values $s$ given the covariate vector $X$. This procedure's advantage is that only the functional form of the conditional means must be correctly specified, rendering it unnecessary to make any more elaborate distribution assumptions of the type demanded by fully parametric models.

The structure of the data entails elementary restrictions that must be considered in the model choice:

$$
\begin{aligned}
& E\left[s_{j} \mid x\right]=\lambda(x ; \beta) \in(0,1) \\
& \sum_{a=1}^{A} E\left(s_{a} \mid X\right)=1 \\
& \operatorname{Pr}\left(s_{j}=0 \mid x\right) \geq 0 \\
& \operatorname{Pr}\left(s_{j}=1 \mid x\right) \geq 0
\end{aligned}
$$

These restrictions imply that the proportional values are restricted to a range of values between 0 and 1 , the sum of the shares for one company must always equal 1 , and there is a nontrivial probability that individual share values may correspond to the limits of the value range, i.e., 0 or 1 .

For the present scenario, for which we selected a conditional means model, the multinomial logit specification is chosen as functional form, as it fulfils the aforementioned 
restrictions (Koch, 2010). This choice gives rise to the following conditional distribution of company skilled-worker demand:

$$
E\left[s_{i j} \mid x_{i}\right]=\lambda(x ; \beta)=\frac{\exp \left\{x_{i} \beta_{j}\right\}}{\sum_{a=1}^{A} \exp \left\{x_{i} \beta_{a}\right\}} \text { with } j=1,2, \ldots, A .
$$

A log-odds transformation is frequently employed as an alternative to this methodology. This admittedly permits linear estimation methods but has the serious drawback of making the coefficients substantially more difficult to interpret and also requires ad hoc adjustments to cope with the limits of the value range, i.e., 0 and 1 (Ramalho et al., 2011).

For the estimation, we employ a quasi-maximum likelihood (QML) estimator ${ }^{\mathrm{i}}$, which supplies robust values even without an ad hoc transformation (Murteira and Ramalho, 2012). As long as the functional form of the conditional means is correctly specified, the QML estimator is consistent, irrespective of the true distribution of $y$ given $x$ (Gourieroux et al., 1984). Therefore, an asymptotic covariance matrix is estimated by means of the robust sandwich estimator proposed by Mullahy (2010).

As not all $\beta_{j}$ are separately identified in the multinomial quasi-likelihood function, it is necessary to normalise to one alternative (Mullahy, 2010). Because of this normalisation, the estimated coefficients can only be interpreted with reference to the particular alternative category used for normalisation, which implies that they are independent of the other alternative(s) that are omitted from this pairwise comparison. Unfortunately, this multinomial logit model problem, also known as the independence of irrelevant alternatives' (IIA), cannot be alleviated in our case. As the validity of the standard econometric methods used to address this issue can be assessed somewhat critically, the meaningfulness of such a test is limited, and we refrain from using one (cf. Cheng and Long, 2007). However, multinomial logit model alternatives, such as the nested logit model used by Dubin (2007), would generate additional problems (Amemiya, 1981) ${ }^{j}$. As the issue of the IIA assumption does not pose a problem in the univariate fractional response case, we additionally estimate five different - thus independent - regressions each of the five different recruitment channels posing as the (sole) dependent variable in one equation (cf. Table S4 in Additional file 4). A comparison of the results reveals mostly negligible discrepancies, suggesting that a potential violation of the IIA assumption in our (multivariate) main regression does not seem to bias the results and conclusions substantially.

Because direct interpretation of these coefficients is thus unsuitable (Crawford et al., 1998), the calculation and interpretation of average partial effects (APEs) is applied ${ }^{\mathrm{k}}$. Because these APEs require the sum of these effects across all existing alternatives for every covariate equals zero, interpretation has to acknowledge this fact.

In the classic multinomial logit model, there is a set of alternatives from which only one can be selected (e.g., choice of one's means of transportation to work), making it binary in nature. In our case, by contrast, several potential alternatives can be chosen in varying, non-binary amounts. Mullahy (2010) shows that a corresponding multinomial quasi-likelihood function $\mathrm{Q}($.$) can be adapted in this$ case $^{\mathrm{m}}$ :

$$
\mathrm{Q}(\beta)=\prod_{i=1}^{N} \prod_{a=1}^{A} \lambda_{a}\left(x_{i} ; \beta\right)^{s_{i a}}
$$




\section{Specification test}

Last, but not least, we examine our choice regarding the functional form specification of the conditional means, as the quasi-maximum-likelihood method, as stated by Gourieroux et al. (1984), provides consistent estimators as long as the specification of the conditional means $\lambda(x)=E[s \mid x]$ is correct. Similar to Koch (2010) and Mullahy (2010), we employ a method similar to the test proposed by Hosmer and Lemeshow (2000), whereby quantiles of the estimated conditional means $\hat{E}\left[s_{i j} \mid x_{i}\right]$ are used and, depending on the chosen number of quantiles, result in multiple test statistics (here 10), the variance of which - due to their sample-like character - is estimated using a bootstrap procedure.

The predicted conditional means of each of the five alternative categories are initially partitioned into a fixed number of quantiles; the deviation of the mean prediction from the mean actual observation for each quantile is then analysed. The relevant test statistics and their sample variations estimated through 1,000 bootstrap loops are presented in Figure S1 in Additional file 5. Almost none of the confidence bands fail to cover the value of zero for any of the deciles of all three possible recruitment channels, which indicates that the multinomial logit is a valid functional form for the conditional means, as the predictions and observations are very similar. The overall test statistics of the conditional moment tests clearly point in the same direction, with a p-value of nearly 1 .

Simulations by Hosmer et al. (1997) show that the choice of the number of groups for the $x^{2}$-based goodness-of-fit test can yield differing results. To account for these differences and test the robustness of our test results, we vary the number of quantiles (as well as the number of bootstrap loops) from 10 to 5 and 20 (bootstrap: 500 and 1,000, respectively), which does not lead to deviating conclusions in our case.

\section{Results and discussion}

Table 2 presents our primary model's estimation results.

\section{Cost-(Benefit)-related factors}

The cost-benefit ratio analysis of apprenticeship shows the following results: First, the greater a company's perceived benefit from in-house IVET, the greater its demand for this form of junior-staff recruitment and the smaller its demand for skilled workers with university degrees from the external labour market. Second, the greater the perceived cost associated with in-house IVET, the less a company relies on the recruitment of highly qualified staff with university degrees; surprisingly, these companies hire significantly more new apprentices (although significance is at a low level). One possible explanation for this somewhat unexpected result is that, holding all other variables fixed companies with higher training costs have to train for specific job requirements and follow an apprenticeship investment strategy. Additionally, it has to be said that higher costs could be balanced by higher benefits thus leading to negative net costs. Unfortunately, information on net costs is not available in the data set.

The above-average remuneration in a firm with a demand for labour - measured by the residuals of a preceding auxiliary first-step wage regression ${ }^{\mathrm{n}}$ (see Table S5 in Additional file 6) - is associated with a significantly greater demand for skilled staff 
Table 2 Average partial effects and their confidence intervals obtained through bootstrapping (CL-L and CL-U) using the multivariate model

\begin{tabular}{|c|c|c|c|c|c|}
\hline \multirow{2}{*}{$\begin{array}{l}\text { Independent variables } \\
\text { Regressors }\end{array}$} & \multicolumn{5}{|c|}{ (Realised and unmet) demand for... } \\
\hline & $\begin{array}{l}\text { New } \\
\text { apprentices }\end{array}$ & $\begin{array}{l}\text { Unskilled } \\
\text { workers }\end{array}$ & $\begin{array}{l}\text { Workers } \\
\text { with IVET } \\
\text { qualifications }\end{array}$ & $\begin{array}{l}\text { Technicians } \\
\text { and master } \\
\text { craftsmen }\end{array}$ & $\begin{array}{l}\text { Workers with } \\
\text { university } \\
\text { degrees }\end{array}$ \\
\hline IVET cost & $.011 *(.006)$ & $-.007(.005)$ & $.006(.007)$ & $-.0002(.003)$ & $-.009 * *(.004)$ \\
\hline IVET benefit & $.020^{* *}(.010)$ & $-.008(.006)$ & $.007(.010)$ & $.001(.004)$ & $-.021 * * *(.006)$ \\
\hline Wage regression residuals & $-.040(.031)$ & $-.030^{* *}(.015)$ & $.028(.026)$ & $.005(.013)$ & $.038^{* * *}(.014)$ \\
\hline Churning rate & $-.770^{* * *}(.166)$ & $.131^{* * *}(.027)$ & $.520^{* * *}(.110)$ & $.043^{*}(.024)$ & $.077^{* *}(.030)$ \\
\hline Employment growth (2009-2010) & $-.132^{* * *}(.014)$ & $.050^{* * *}(.012)$ & $.084^{* * *}(.017)$ & $-.006(.007)$ & $.004(.010)$ \\
\hline Share of vacancies & $.050(.036)$ & $-.060^{* *}(.027)$ & $-.032(.043)$ & $-.013(.020)$ & $.054^{* *}(.026)$ \\
\hline Collective agreement & $.024(.015)$ & $-.003(.011)$ & $-.014(.018)$ & $-.005(.008)$ & $-.002(.012)$ \\
\hline Works council & $.030(.019)$ & $-.010(.014)$ & $-.046^{* *}(.022)$ & $.000(.011)$ & $.026^{* *}(.013)$ \\
\hline Superior technical facilities & $.022^{*}(.013)$ & $.007(.011)$ & $-.045^{* * *}(.016)$ & $.011(.007)$ & $.006(.009)$ \\
\hline Frequent change of products & $.017(.020)$ & $-.008(.017)$ & $-.001(.024)$ & $.001(.011)$ & $-.009(.014)$ \\
\hline Focus on new products & $-.011(.016)$ & $-.011(.011)$ & $-.006(.017)$ & $.008(.008)$ & $.019 *(.010)$ \\
\hline $\begin{array}{l}\text { Focus on price as primary } \\
\text { competitive factor }\end{array}$ & $.010(.018)$ & $.037^{* * *}(.014)$ & $-.046^{* *}(.021)$ & $-.010(.008)$ & $.009(.013)$ \\
\hline Share of unskilled staff & $-.364(.242)$ & $.390^{* * *}(.114)$ & $-.072(.172)$ & $.045(.047)$ & $.0003(.068)$ \\
\hline $\begin{array}{l}\text { Share of staff with } \\
\text { IVET qualifications }\end{array}$ & $-.275(.253)$ & $.041(.115)$ & $.168(.170)$ & $.021(.043)$ & $.044(.064)$ \\
\hline $\begin{array}{l}\text { Share of technicians } \\
\text { and master craftsmen }\end{array}$ & $-.240(.281)$ & $-.002(.145)$ & $-.196(.221)$ & $.263^{* * *}(.047)$ & $.175^{* *}(.078)$ \\
\hline $\begin{array}{l}\text { Share of staff with } \\
\text { university degree }\end{array}$ & $-.271(.254)$ & $-.048(.125)$ & $-.269(.186)$ & $.116^{* *}(.047)$ & $.473^{* * *}(.060)$ \\
\hline Further training & $.019(.024)$ & $-.050^{* *}(.020)$ & $-.001(.027)$ & $.012(.011)$ & $.020(.018)$ \\
\hline Manufacturing & $.071^{* *}(.028)$ & $.047^{* *}(.023)$ & $-.105^{* * *}(.031)$ & $-.043^{* *}(.019)$ & $.030 *(.016)$ \\
\hline Commerce and repair & $.098^{* * *}(.032)$ & $.014(.025)$ & $-.055(.035)$ & $-.044^{*}(.023)$ & $-.014(.018)$ \\
\hline Private Services & $.055^{* *}(.027)$ & $.019(.022)$ & $-.064^{* *}(.030)$ & $-.049 * * *(.019)$ & $.039 * *(.018)$ \\
\hline $\begin{array}{l}\text { Public service, education, } \\
\text { teaching }\end{array}$ & $-.078^{* * *}(.027)$ & $.014(.022)$ & $.043(.034)$ & $-.034^{*}(.020)$ & $.055^{* * *}(.018)$ \\
\hline Young company & $-.003(.032)$ & $-.033^{*}(.018)$ & $.056(.035)$ & $.010(.019)$ & $-.029(.018)$ \\
\hline Company size-class 2: 20-99 & $.004(.031)$ & $.028^{*}(.017)$ & $-.029(.031)$ & $.018(.013)$ & $-.020(.016)$ \\
\hline Company size-class 3: 100-199 & $.040(.041)$ & $.004(.020)$ & $-.080^{* *}(.038)$ & $.019(.015)$ & $.024(.020)$ \\
\hline Company size-class 4: 200+ & $.026(.040)$ & $.025(.020)$ & $-.087^{* *}(.036)$ & $.007(.013)$ & $.028^{*}(.017)$ \\
\hline Western Germany & $.016(.017)$ & $.009(.012)$ & $-.035^{*}(.018)$ & $.010(.008)$ & $-.001(.011)$ \\
\hline Number of observations & & & 1,567 & & \\
\hline
\end{tabular}

Source: BIBB Establishment Panel on Training and Competence Development. Significance is denoted as *** $p<0.01$, ** $p<0.05,{ }^{*} p<0.1$.

with university degrees, who have to be recruited through the external labour market. In contrast, a company's demand for unskilled workers is significantly lower in companies with above-average salaries and wages. The result thus indicates that companies with above-average remuneration attempt to meet their demands for highly qualified labour through wage premiums and are less likely to recruit unskilled workers.

\section{Labour mobility-related factors}

On the one hand, the churning rate, which measures the proportion of worker mobility that cannot be explained by changes in the total number of employees, has a 
significantly negative influence on the demand for new apprentices. These firms potentially view the training investment as excessively risky because of a large probability that trainees leave the firm after they complete training. Conversely, these findings also indicate that companies with a lower churning rate, implying a stronger employee retention, a high stock of specific human capital or potentially even difficulties with recruiting from the external labour market opt for the 'make' decision and hire new apprentices.

On the other hand, it has a highly significant positive influence on the recruitment of the other four incorporated categories that a firm can utilize to meet its labour demands. Additionally, it is worthwhile to note that the coefficient for the external recruitment of vocationally qualified workers is much greater than those of the other categories. These findings confirm the results of other studies that skilled workers trained in-house are more closely attached to their training company.

Furthermore, companies reporting employment growth since the economic and financial crisis of 2008 and 2009 show a higher demand for vocationally qualified skilled and unskilled workers and a lower demand for new apprentices. This could mean that during an economic boom, in-company IVET simply takes too long and is therefore less attractive than recruitment of already-qualified workers via the external labour market. External recruitment can potentially be accomplished more quickly than training apprentices, which takes three to three-and-a-half years ${ }^{\circ}$.

The proportion of vacant jobs for employees and apprentices (construction explained in Table S2 in Additional file 2) is positively correlated with the demand for externally skilled workers with university degrees; in contrast, it is also associated with a significantly lower demand for unskilled labour. This result may be explained by the fact that a high share of vacant jobs originates in the STEM fields of science, technology, engineering and mathematics (Helmrich and Zika, 2010), which usually require a high degree of qualification.

\section{Institution-related factors}

The existence of a works council is associated with a lesser demand for externally skilled staff with IVET qualification and a greater demand for university-trained workers. Dustmann and Schoenberg (2012) deliver a possible explanation to support this finding; according to their model, training investment is higher when firms can credibly assure potentially new apprentices that they will abide by the implicit promises of the training agreement. Arguing that a works council is a crucial institution to perform this function might explain the insignificant coefficient of the existence of a works council on the demand for new apprentices and the highly negative significant effect on the demand for already-qualified workers with IVET qualifications. Our results about the affiliation to a collective agreement are inconclusive.

\section{Technology- and market-related factors}

If the surveyed establishment assesses the technical standard of its plant and machinery as superior to that of its competitors, the demand for new apprentices is higher, to a large extent decreasing the demand for already-qualified workers with IVET degrees. A possible explanation for this result is that the superior technical standard of a company's plant and machinery is often rooted in specific characteristics of that particular 
company. In this case, it makes less sense to recruit vocationally qualified skilled workers to operate the machinery because the company's own apprentices can be trained at low cost in all company-specific work content during their comparatively low-paid IVET phase. Furthermore, due to their specific knowledge base, a component of their training cannot be transferred to another company. This non-transferable training allows the training company to potentially pay its newly qualified graduates of inhouse IVET a wage lower than their individual productivity and thereby amortise initial vocational training costs.

In contrast, firms that focus on the development of new products and private services tend to rely more on the external recruitment of workers with university degrees. In addition, companies that consider price as the primary competitive factor seem to rely more on (cheaper) unskilled labour and less on (more expensive) skilled workers with IVET qualification.

Thus, to sum up, firms with superior technological standing seem to attribute comparative advantages to new apprentices, as skills learned are frequently firm-specific to that plant and machinery and therefore require (lengthy) familiarisation. In addition, apprenticeship training could also be seen as a source for process innovation. In contrast, highly qualified workers with university degrees are preferred to develop new products. Moreover, when a firm places greater importance on costs, it tends to opt for unskilled labour, whereas already-qualified workers with IVET degrees seem to be favoured in the opposite case.

\section{Employment structure and skill-related factors}

The greater the proportion of university graduates among its staff, the greater the firm's demand for recruitment of such workers, verifying the hypothesis that companies tend to reproduce their existing workforce with respect to its educational structure. Moreover, the demand for technicians and master craftsmen is higher in these firms. Because the same holds true for the share of staff technicians and master craftsmen, this finding can be taken as an indication for the complementary relationship between those two groups of skilled workers. Similarly, the greater the proportion of unskilled workers on staff, the higher the demand for similarly educated employees and the lower the demand for new apprentices, where the latter coefficient is large but insignificant. Therefore, the assumption that the recruitment of these two groups of workers are opposing strategies cannot be thoroughly confirmed. Although the coefficient for the impact of the share of skilled workers with IVET qualifications on the recruitment of such workers is insignificant, its positive coefficient and the positive and significant coefficients for the other shares together comprise a strong indicator favouring the reproduction hypothesis.

The significantly negative impact of the establishments' further training activities on their demand for unskilled labour agrees with other empirical findings, as unskilled workers exhibit much lower further training participation (for the German case, confer Leber and Moeller, 2008).

\section{Company structure-related factors}

Interestingly, all economic branch dummies produce significant results but must always be interpreted alongside the primary sector (including mining, energy and the building 
industries) as a reference category. These results can be summarized as follows: First, in manufacturing, 'commerce and repair' and other private service sectors, the demand for new apprentices is higher; conversely, the demand for workers with IVET qualifications and externally recruited technicians and master craftsmen is lower, although not always statistically significant. However, the demand for already-qualified workers with university degrees is higher in manufacturing, private services and in 'public service, health and social care, education and teaching', and in the latter case at the expense of the demand for technicians, master craftsmen, and new apprentices for in-house vocational training.

In summary, our findings show that companies' willingness to train their own apprentices is positively correlated with the company's affiliation to a sector in which establishments traditionally train their own junior staff. For example, traditionally there is a relatively high importance of apprenticeship in the manufacturing sector.

In contrast, in terms of firm size, our data is not particularly conclusive. Similarly, our results about a firm's age and location are inconclusive.

So far, the discussion has been restricted to the statistical significance of the coefficients. Therefore, we now briefly address their economic significance to provide a better understanding of their relative importance. By comparing the effect of a change by one standard deviation in a certain continuous regressor on one of the dependent variables in terms of standard deviations reveals the importance of the churning rate, which is responsible for the strongest differences over all channels in how firms fulfil their demand for labour. Another influence factor with substantial economic importance is whether a firm has experienced an employment growth within the last year. Furthermore, the variables indicating the current workforce structure of an establishment exert substantial impacts, albeit in each case only for the respective type of labour demand in line with the reproduction mechanism.

\section{Conclusions}

Companies have to make a fundamental choice to meet their labour demands by providing their own apprenticeship training or by recruiting unskilled or alreadyqualified staff from the external labour market. The previous analysis of influential factors in the company's use of the five different recruitment strategies to meet this demand shows that there are not only specific patterns for single recruitment options but also common patterns of influential factors for almost all recruitment options.

Factors related to the cost and benefit of apprenticeship training turn out to influence the training decision. Therefore the first hypothesis can be accepted. Our findings indicate that companies with a lower churning rate, implying stronger employee retention, a high stock of specific human capital or potentially even difficulties with recruiting from the external labour market opt for the 'make' decision and hire new apprentices. In this sense, some evidence for the validity of the second hypothesis is given. However, institution-related factors and those related to the companies' technological or market strategies only play a role for single recruitment strategies and have no common 
patterns of influential factors. Thus, these factors demonstrate no significant influences on the third and fourth hypothesis.

In terms of the relationship between different recruitment strategies, it can be carefully assumed that the 'make' and 'buy' decision depict alternative strategies if a rapid reproduction of the employee qualification structure and particularly when workers with IVET qualifications are required. Our results show that these circumstances lead to negative consequences for apprentice demand. High churning rates and high employment growth rates seem to produce a similar effect. This finding conflicts with earlier results (Troltsch and Walden, 2010).

Although the demand for apprentices was still strongly connected with the demand for skilled workers in the first decade of the $21^{\text {st }}$ century (ibid.), this relationship seems to gradually dissolve according to our findings. The relationship between apprentices training and external recruitment of workers could have progressively changed due to changing economic and societal conditions. However, due to the present study's methodological approach, our findings only depict preliminary evidence regarding the question of whether the different recruitment options are compatible or opposing. Furthermore, it has to be acknowledged that our analysis is only based on cross-sectional data. Hence, we cannot rule out the possibility that some of the relevant variables such as the demand for workers from the external labour market or the benefit of apprenticeship could change over time and also be dependent of the business cycle. Accordingly, this question can only be examined through further data collection and analyses. Considering Germany's serious impending demographic crisis with a declining number of schoolchildren, it remains to be seen how the relationship between internal and external recruitment strategies will develop in the medium-term. If this trend should continue and if labour and education policy does not take the appropriate measures the German economy will most likely face serious problems because of increasing shortages of skilled labour.

\section{Endnotes}

${ }^{a}$ Other explanatory approaches to company IVET, for example that of Lazear (2000), are found in Wolter and Ryan (2011).

bIf non-training companies are asked directly why they do not provide IVET, a series of manifest reasons are given. For Germany, particular reference is made to high IVET costs, the lack of time for IVET, too many regulations and insufficient time spent in the workplace (Schoenfeld et al. 2010: 180).

${ }^{\mathrm{c}}$ On possible substitution processes between skilled staff trained in-house and higher qualified skilled staff, no robust empirical and statistically underpinned studies are yet available.

${ }^{\mathrm{d}}$ This paper uses data from the BIBB Establishment Panel on Training and Competence Development which is a product of the Federal Institute for Vocational Education and Training (BIBB), doi:10.7803/371.11.1.2.10

${ }^{\mathrm{e}}$ For the imputations, censored regression models were specified that included structural variables, such as the legal form, the commitment to a collective agreement, the number of employees, the shares of special employee groups and other company characteristics. Imputations were made on nearly 60 total variables. These variables 
primarily include particularly sensitive indicators, such as the gross wage and salary total, investment totals, and average gross wage by employee group. (for further information, cf. Gerhards et al., 2013).

${ }^{\mathrm{f}}$ It is worth noting that the shares displayed in Table 1 are unweighted, and these proportions thus do not necessarily depict the reality of companies' recruitment behaviour in Germany.

${ }^{\mathrm{g}}$ While in larger firms relative demand for new apprentices and for workers with a university degree is high est, smaller firms tend to rely the most on already-qualified workers with IVET qualifications from the labour market. In general, it appears obvious that the larger the firm, the less likely it is that it has no demand for one of the different types of workers at all as well as that it meets its demand for work by relying on one channel exclusively.

${ }^{\mathrm{h}}$ Other multivariate cases include those by Mullahy and Robert (2010), Mullahy (2004, 2010) and Koch (2010), as well as studies from other thematic areas, e.g., agricultural (Mu et al., 2013) or transportation research (Ye and Pendyala 2005).

iAlternatively, an estimation using nonlinear least squares (NLS) is also conceivable. In the course of their simulation study, Murteira and Ramalho (2012) concluded that the QML method has advantages over NLS.

In the nested logit model, for example, a hierarchical choice structure among the alternatives is assumed, which is not appropriate in our case.

kAlthough it would be conceivable to analyse each of the five shares individually, i.e., univariately, instead of using the multivariate model, this option would disregard the nature of the data, as the shares must add up to 100 per cent and thus stand in direct relationship to each other. A sample evaluation of five univariate regressions, including the average partial effects, is illustrated in Table S4 in Additional file 5. As can be seen, the results are very similar to those of the multivariate model.

${ }^{\mathrm{l}} \mathrm{We}$ are fully aware of potential endogeneity issues occurring throughout our multivariate analysis. For instance, firms with a good reputation or with a highly professionalized recruitment strategy, which are both unobserved in our data, should attract more productive workers and face less problems in filling their vacancies, have lower labour turnover and offer higher wages. However, because there is no comparable study, the aim of our paper is to achieve an exploratory overview of the correlation of firms' structure and their demands for different kinds of labour. Further research focusing a single important correlation should account for these issues, though.

${ }^{\mathrm{m}}$ We would like to express our thanks to John Mullahy for kindly providing his selfwritten program in Stata's Mata language and helpful tips regarding its use.

${ }^{\mathrm{n}}$ To convey information on firms' relative remuneration level we calculated residuals from regressing the total wage bill divided by the number of employees of a firm (in logs) on several firm characteristics, e.g. firm size (in categories) and sector affiliation. To adjust for the fact that we divide by all employees irrespective of their individual characteristics, we additionally include information on the shares of women, part-time workers as well as on the workforce composition with regard to their educational attainment.

${ }^{\circ}$ It should be noted here that during the observation period, after the economic and financial crisis, a distinct rebound in employment occurred. 


\section{Additional files}

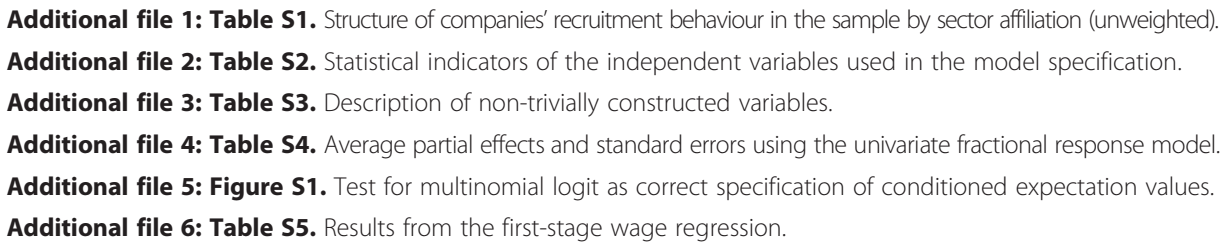

\section{Competing interests}

The authors declare that they have no competing interests.

\section{Authors' contributions}

LB and GW drafted the concept of the paper. KT and GW carried out the literature review and theoretical considerations. PG and LB carried out the empirical analyses and discussion of the results. All authors read and approved the final manuscript.

\section{Author details}

${ }^{1}$ Friedrich-Alexander University Erlangen-Nürnberg, Nürnberg, Germany. ${ }^{2}$ Department "Establishments and Employment", Institute for Employment Research (IAB), Nürnberg, Germany. ${ }^{3}$ Department "Sociology and Economics of Vocational Education and Training", Federal Institute for Vocational Education and Training, Bonn, Germany.

Received: 2 March 2014 Accepted: 15 October 2014

Published online: 13 November 2014

\section{References}

Acemoglu D, Pischke JS (1998) Why do firms train? Theory and evidence. Q J Econ 113(1):79-119

Acemoglu D, Pischke JS (1999a) Beyond Becker: training in imperfect labor markets. Econ J 109(453):F112-F142

Acemoglu D, Pischke JS (1999b) The structure of wages and investment in general training. J Polit Econ 107(3):539-572

Amemiya T (1981) Qualitative response models. A survey. J Econ Lit 19(4):1483-1536

Autor DH, Levy F, Murnane RJ (2003) The skill content of recent technological change: an empirical exploration. Q J Econ 118(4):1279-1333

Becker GS (1964) Human capital. A theoretical and empirical analysis, with special reference to education. National Bureau of Economic Research. General series, 80, New York

Beicht U, Walden G, Herget H (2004) Costs and Benefits of In-Company Vocational Education and Training in Germany. Bertelsmann, Bielefeld

Bellmann L, Janik F (2007) To recruit skilled workers or to train one's own? Vocational training in the face of uncertainty as to the rate of retention of trainees on completion of training. J Labour Market Res 40(2/3):205-220

Bellmann L, Krekel EM, Stegmaier J (2010) Aus- und Weiterbildung - Komplemente oder Substitute? Zur Bildungsbeteiligung kleinerer und mittlerer Betriebe in Deutschland. DIE-Zeitschrift für Erwachsenenbildung 33(1):41-54

Blatter M, Muehlemann S, Schenker S, Wolter S (2012) Hiring costs of skilled workers and the supply of firm-provided training. IZA Discussion Paper No. 6344. Bonn

Cheng S, Long JS (2007) Testing for IIA in the multinomial logit model. Sociol Methods Res 35(4):583-600

Crawford DL, Pollak RA, Vella FGM (1998) Simple inference in multinominal and ordered logit. Econ Rev 17(3):289-299

Dietrich H, Gerner HD (2007) The determinants of apprenticeship training with particular reference to business expectations. J Labour Market Res 40(2/3):221-233

Dubin JA (2007) Valuing intangible assets with a nested logit market share model. J Econ 139(2):285-302

Dustmann C, Schoenberg U (2012) What makes firm-based vocational training schemes successful? The role of commitment. Am Econ J Appl Econ 4(2):36-61

Gerhards C, Mohr S, Troltsch K (2013) The BIBB training panel. An establishment panel on training and competence development. J Appl Soc Sci 133(1):1-18

Gericke N (2014) Alter der Auszubildenden und Ausbildungsbeteiligung der Jugendlichen im dualen System. In: Bundesinstitut für Berufsbildung (ed) Datenreport zum Berufsbildungsbericht 2014. Bertelsmann, Bielefeld, pp 137-144

Gourieroux C, Monfort A, Trognon A (1984) Pseudo maximum likelihood methods. Theory. Econometrica 52(3):681-700

Helmrich R, Zika G (2010) Beruf und Qualifikation in der Zukunft: Modellrechnungen zu den Entwicklungen in Berufsfeldern und Qualifikationen bis 2025. Bertelsmann, Bielefeld

Hosmer DW, Lemeshow S (2000) Applied Logistic Regression, 2nd edn. Wiley, New York (A Wiley-Interscience publication)

Hosmer DW, Hosmer T, Le Cessie S, Lemeshow S (1997) A comparison of goodness-of-fit tests for the logistic regression model. Stat Med 16(9):965-980

Katz E, Ziderman A (1990) Investment in general training. The role of information and labour mobility. Econ J 100(403):1147-1158

Koch SF (2010) Fractional Multinomial Response Models with an Application to Expenditure Shares. Mimeo, Pretoria

Kriechel B, Muehlemann S, Pfeifer H, Schuette M (2012) Works councils, collective bargaining and apprenticeship training. IZA Discussion Paper No. 6497. Bonn

Lazear EP (2000) The future of personnel economics. Econ J 110(467):F611-F639

Leber U, Moeller I (2008) Weiterbildungsbeteiligung ausgewählter Personengruppen. J Appl Soc Sci 128(3):405-429

Lindley RM (1975) Demand for apprentice recruits by the engineering industry: 1951-1971. Scot J Polit Econ 22(1):1-24 
Merrilees WJ (1983) Alternative models of apprenticeship recruitment: with special reference to the British engineering industry. Appl Econ 15(1):1-21

Mu JE, McCarl BA, Wein AM (2013) Adaption to Climate Change: Changes in Farmland Use and Stocking Rate in the U. S. Mitig Adapt Stateg Glob Change 18(6):713-730

Muehlemann S, Schweri J, Winkelmann R, Wolter SC (2007) An empirical analysis of the decision to train apprentices. Labour 21(3):419-441

Mullahy J (2004) Squandering Time? Economic Aspects of Children's Time Use. (Working Paper, University of Wisconsin) Mullahy J (2010) Multivariate Fractional Regression Estimation of Econometric Share Models. NBER Working Paper No. 16354 Cambridge, Mass

Mullahy J, Robert SA (2010) No time to lose. Time constraints and physical activity in the production of health. Rev Econ Househ 8(4):409-432

Murteira JMR, Ramalho JJS (2014) Regression analysis of multivariate fractional data. Econometric Rev. doi:10.1080/07474938

Papke LE, Wooldridge JM (1996) Econometric methods for fractional response variables with an application to 401 (k) plan participation rates. J Appl Econ 11(6):619-632

Papke LE, Wooldridge JM (2008) Panel data methods for fractional response variables with an application to test pass rates. J Econ 145(1/2):121-133

Porter ME (2004) Competitive strategy. Techniques for analysing industries and competitors. NY Press, New York

Ramalho EA, Ramalho JJS, Murteira JMR (2011) Alternative estimating and testing empirical strategies for fractional regression models. J Econ Surv 25(1):19-68

Schoenfeld G, Wenzelmann F, Dionisius R, Pfeifer H, Walden G (2010) Kosten und Nutzen der dualen Ausbildung aus Sicht der Betriebe. Ergebnisse der vierten BIBB-Kosten-Nutzen-Erhebung. Bertelsmann, Bielefeld

Schweri J, Müller B (2007) Why has the share of training firms declined in Switzerland? J Labour Market Res 40(2/3):149-168

Stevens M (1994) An investment model for the supply of training by employers. Econ J 104(424):556-570

Troltsch K, Walden G (2010) Beschäftigungsentwicklung und Dynamik des betrieblichen Ausbildungsangebotes. Eine Analyse für den Zeitraum 1999 bis 2008. J Labour Market Res 43(2):107-124

Walden G (2007a) Short-term and long-term benefits as determinants of the training behaviour of companies. J Labour Market Res 40(2/3):169-191

Walden G (ed) (2007b) Qualifikationsentwicklung im Dienstleistungsbereich. Herausforderungen für das duale System der Berufsausbildung. Bertelsmann, Bielefeld

Wolter SC, Ryan P (2011) Apprenticeship. In: Hanushek EA, Machin S, Woessmann L (eds) Handbook of the economics of education. North-Holland, Amsterdam, Heidelberg, Handbooks in economics, 26, pp 521-576

Ye X, Pendyala RM (2005) A Model of Daily Time Use Allocation Using Fractional Logit Methodology. In: Mahmassani HS (ed) Transportation and Traffic Theory. Pergamon, Elsevier Science Ltd., Oxford, pp 507-524

doi:10.1186/s40461-014-0009-x

Cite this article as: Bellmann et al: Make or buy: train in-company or recruit from the labour market? Empirical Research in Vocational Education and Training 2014 6:9.

\section{Submit your manuscript to a SpringerOpen ${ }^{\circ}$ journal and benefit from:}

- Convenient online submission

Rigorous peer review

- Immediate publication on acceptance

- Open access: articles freely available online

High visibility within the field

- Retaining the copyright to your article

Submit your next manuscript at $\boldsymbol{~ s p r i n g e r o p e n . c o m ~}$ 